УДК 656.224.003.077

\title{
ДОСЛІДЖЕННЯ ТА АНАЛІЗ ПРИЧИН НЕДОСТАТНЬОГО РОЗВИТКУ ШВІДКІСНОГО ЗАЛІЗНИЧНОГО РУХУ В УКРАЇНІ
}

Канд. техн. наук Я.В. Запара, магістрант О.В.Биков

\section{ИССЛЕДОВАНИЯ И АНАЛИЗ ПРИЧИН НЕДОСТАТОЧНОГО РАЗВИТИЯ СКОРОСТНОГО ЖЕЛЕЗНОДОРОЖНОГО ДВИЖЕНИЯ В УКРАИНЕ}

Канд. техн. наук Я.В. Запара, магистрант А.В.Быков

\section{RESEARCH AND ANALYSIS OF SHVIDKISNOHO DUE TO INSUFFICIENT RAIL TRAFFIC IN UKRAINE}

Candidate of techn. sciences Y. Zapara, master student O. Bykov

У статті описано світові моделі реформування залізничного транспорту та ймовірність розвитку однієї з моделей на залізничному транспорті Украӥни. Розглянуто і проаналізовано роботу швидкісних поїздів. Окреслено аспекти, за умовами яких швидкісний рухв Україні набуде подальшого розвитку.

Ключові слова: пришвидшений рух, швидкісний рух, реформування, конкурентоспроможність, модель, швидкість руху.

В статье описаны мировые модели реформирования железнодорожного транспорта $u$ вероятность развития одной из моделей на железнодорожном транспорте Украины. Рассмотрена u проанализирована работа скоростных поездов. Очерчены аспекты, по условиям которых скоростное движение на Украине получитдальнеймееразвитие.

Ключевые слова: ускоренное движение, скоростное движение, реформирование, конкурентоспособность, модель, скорость движения.

Rail Ukraine is one of the most important branches of production infrastructure of the national economy - the basis of the transport system of Ukraine. Future of Railway Transport of Ukraine connected with the implementation of strategic decisions, including reforming and implementing large-scale innovative projects. One of the most relevant today is the organization of high-speed passenger traffic.

The future of passenger rail transportation in Ukraine depends on the further development and improvement of highways and the future - high-speed highways. This will help increase the competitiveness of rail transport in the transport market posluh.

$V$ article describes the global model railway reform and the likelihood of one of the models in rail transport Ukraine. Considered and analyzed the work of high-speed trains. Outlined aspects, under which high-speed movement in Ukraine will take further development.

Keywords: acceleratedmotion, movementspeed, reform, competitiveness, model, speed.

Вступ. Залізничний транспорт України є однією 3 найважливіших галузей виробничої інфраструктури національної економіки основою транспортної системи України. Майбутнє залізничного транспорту України пов'язане 3 реалізацією стратегічних рішень, серед яких реформування галузі та впровадження широкомасштабних інноваційних проектів. Одним 3 найбільш актуальних на сьогодні $€$ організація швидкісного пасажирського руху.
Майбутнє пасажирських перевезень на залізничному транспорті України залежить від подальшого розвитку й удосконалення швидкісних магістралей, а надалі - створення високошвидкісних магістралей [1]. Це допоможе підвищити конкурентоспроможність залізничного транспорту на ринку транспортних послуг.

Постановка проблеми у загальному вигляді та її зв'язок із важливими науковими та практичними завданнями. Україна на 
шляху розвитку швидкісного залізничного руху значно відстає від розвинених країн (Польща, Німеччина, Росія, Китай та ін.). Початком роботи швидкісних поїздів в Україні є 2012 рік, коли рух розпочато на основних ділянках залізниць, які з'єднували міста проведення Євро-2012 (Харків, Донецьк, Київ, Львів). Денні швидкісні поїзди стали реальними конкурентами авіаційному транспорту як за часом переміщення, так і за вартістю проїзду. Отже, розвиток швидкісного залізничного транспорту $є$ перспективним, має достатньо переваг на ринку пасажирських перевезень, але потребує значних капіталовкладень [2].

Відповідно до впровадження швидкісного руху пасажирських поїздів на залізницях України у 2004-2015 роках, за рахунок модернізації та реконструкції основних напрямків залізниць України впроваджено швидкісний рух, який потребує розвитку та постійного переоснащення в межах сучасних технічних, технологічних, організаційних та інформаційних рішень [3].

Аналіз останніх досліджень i публікацій. За останні роки достатньо уваги було приділено питанням розвитку високошвидкісного руху в Україні. У наш час розроблено наукові підходи до ефективності функціонування швидкісного рухомого складу, які спрямовані на раціональне його використання. Слід відзначити напрацювання останніх років таких учених та практиків: Барабаш Ю.С., Бутько Т.В., Кірпа Г.М., Манжола В.А., Прохорченко А.В., Філіпенко А.С. та ін. [1].

Аналіз публікацій указує на можливість подальшого розвитку швидкісного залізничного руху в Україні, враховуючи світовий досвід 3 цього питання.

Визначення мети та задачі дослідження. Метою роботи єдослідження світового досвіду впровадження швидкісного залізничного руху та можливість його подальшого розвитку в Україні. Задачі дослідження полягають в аналізі основних моделей світового розвитку швидкісного залізничного руху та наданні відповідних пропозицій щодо розвитку його в Україні [4].

Основначастина. Значно підвищити конкурентоспроможність залізничного транспорту можна, впроваджуючи та розвиваючи так званий пришвидшений рух (до 160 км/год) на основі наявних колій. Саме такий шлях дає можливість галузі залізничного транспорту зберегти й найефективніше використовувати існуючий науково-технічний потенціал для структурних і технологічних змін та збереження конкурентних переваг перед іншими видами транспорту [5].

Розвиток залізничного транспорту спрямований на забезпечення зростаючих потреб у перевезеннях вантажів та пасажирів в умовах функціонування економіки України за дотримання високих стандартів якості в обслуговуванні споживачів. Це можливо на основі ефективного функціонування й модернізації залізничного транспорту, постійного оновлення техніки, упровадження сучасних технологій обслуговування, удосконалення процесів організації праці й управління на залізничному транспорті тощо [6].

Досвіду створення швидкісного залізничного транспорту в Україні немає. Тому під час упровадження швидкісного руху врахованодосягнення Західної Європи, а також Японії, США, Росії та інших країн. Існують нижченаведені світові моделі швидкісного залізничного руху [4].

Перша модель - європейська передбачає, що вагонами i локомотивами володіють приватні компанії, що конкурують між собою. Коліями, вокзалами та іншою інфраструктурою володіє держава або держкомпанія, така як Укрзалізниця. Оператори-приватники платять за використання державної інфраструктури. 3 1991 року в Свропейському Союзі послідовно проводилася лібералізація ринку залізничних перевезень. Від 2010 року вільну конкуренцію встановлено на ринку пасажирських перевезень. Тоді ж почали з'являтися перші приватні пасажирські поїзди i почалося проникнення на сусідні ринки (наприклад німецьких перевізників - у Польщу та Францію). Перевізники самі встановлюють тарифи i залучають клієнтів. Наглядає за свободою конкуренції держава. Однак, враховуючи українські реалії, $\epsilon$ ризик дискримінації одних компаній на користь інших [4].

Друга модель передбачає, що держава володіє й інфраструктурою і рухомим складом, але на ринок залізничних перевезень допускаються приватні компанії, щоб завдяки конкуренції підвищити якість обслуговування. 
Третя модель реалізована у США, Канаді, Бразилії та Мексиці. Вона передбачає існування кількох залізничних компаній, подібних Укрзалізниці. Тобто в їхньому володінні перебувають шляхи i поїзди, a конкурують вони між собою внаслідок того, що пропонують перевезення за альтернативними маршрутами (3 точки А в точку Б можна проїхати різними залізничними лініями) [4].

Найперспективніше для залізничного транспорту України розвивати так званий пришвидшений рух (до 160 км/год) на основі наявних шляхів. Йдеться про поступове впровадження швидкісного руху з адаптацією до нових вимог нинішньої інфраструктури. Перші поїзди для пришвидшеного руху з'явилися в Україні до Євро-2012 i, незважаючи на всі несправності i труднощі на початку експлуатації, успішно почали конкурувати 3 авіакомпаніями на найбільш привабливих маршрутах: Київ - Донецьк, Київ - Харків, Київ - Львів. Станом на 1 січня 2014 року в Україні курсують 10 швидкісних поїздів "IНTЕРСІTI+", з рухомим складом корейського виробництва HYUNDAI та двома поїздами "IHTEPCITI" чеського виробництва "SKODA". Максимальна швидкість обох видів рухомого складу становить 160 км/год. Найбільшим попитом користуються поїзди "IНTЕРСІTI+", що курсують між Києвом та Харковом. На цьому напрямку курсують 3 швидкісні поїзди [7].

Висока середня населеність поїздів пояснюється малим терміном поїздки (4 год 36 хв - 4 год 48 хв) та зручним графіком руху. Найменшим попитом користувалися поїзди "IHTEPCITI+", що курсували між Києвом та Донецьком. Низька середня населеність поїздів між Києвом та Донецьком пояснюється великим терміном поїздки - майже 7 год, ціна квитків за цим напрямом на поїзди категорії "IHTEPCITI+" була найвищою, що пояснюється відстанню курсування. Ураховуючи ергономічні особливості вагонів та втомлюваність пасажирів, можна сказати, що люди віддають перевагу зручнішому та дешевшому нічному поїзду. На напрямку Київ - Дніпропетровськ - Київ поїзд "IНTЕРСТTI+" їде швидше, ніж нічний швидкий поїзд у 1,5 рази [7].

Основними аспектами, за умов яких не розвивається швидкісний рух на залізницях України, є: кардинальне підвищення технічного рівня інфраструктури залізниць, організація виробництва швидкісного рухомого складу та іншої залізничної техніки, створення нових комп'ютерних систем, засобів передачі енергії, інформації, освоєння нових матеріалів та інші проблеми, що зумовлює потребу у розвитку не тільки транспортної, а й інших галузей економіки і насамперед машинобудування, металургії, виробництва засобів автоматики та обчислювальної техніки, будівельної індустрії [8].

Удосконалення швидкісного руху полягає не тільки в скороченні кількості $n$ та часу зупинок $t_{3}$ на проміжних станціях, а й у підвищенні ходової швидкості руху поїзда:

$$
V_{x}=\frac{2^{n L L}}{2^{N N t_{x}}}
$$

де $\sum N L$ - сумарні поїздо-кілометри на дільниці;

$\sum N t_{x}$ - сумарні поїздо-години в русі на дільниці без урахування зупинок поїздів та часу, затраченого при цих зупинках на розгін та гальмування,

$$
t_{x}=\frac{L_{\text {nepp }}}{V_{x}}+t_{p}+t_{y}
$$

де $L_{\text {пер }}$ - довжина перегону, км;

$V_{x}$ - ходова швидкість поїзда, км/год;

$t_{p}$ - час на розгін, год;

$t_{y}$ - час на уповільнення, год.

Підвищити ходову швидкість поїзда $V_{x}$ можливо за рахунок удосконалення верхньої будови колії $V_{K 1}$ та закупівлі нового рухомого складу $V_{K 2}$ (рисунок).

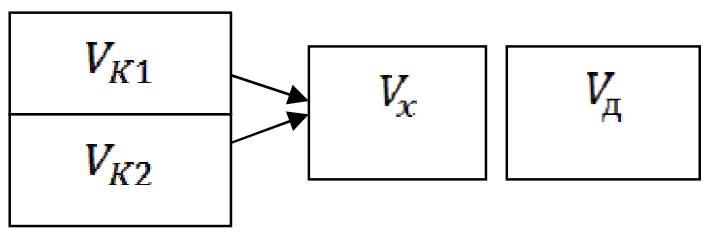

Рис. Схема залежності дільничної швидкості $V_{\text {д }}$ від конструкційних $\left.V_{K 1}\right), V_{K 2}$ параметрів

Як бачимо, $V_{K 1}$ та $V_{K 2}$ взаємодоповнюють один одного і при відсутності однієї складової неможливо досягти бажаного результату. Завдяки $V_{K 1}$ та $V_{K 2}$ підвищиться $V_{x}$ та $V_{\text {д }}$ відповідно зміниться. Тому укладання «оксамитового шляху» та закупівля швидкісного рухомого складу дасть змогу 
скоротити час прямування та підвищитирівень комфорту в дорозі [9].

Після реконструкції дільниці «оксамитовим шляхом» та закупівлі нового швидкісного рухомого складу корейського або чеського виробництва з'явиться можливість ефективніше використовувати швидкісний режим, який досягатиме 200 км/год, та відчувати себе комфортно пасажирам при використанні даного виду послуг.

Головними етапами реконструкції колії є:

- упровадження технології для створення суцільнозварної безстикової колії на перегонах від станції до станції;

- упровадження нових конструкцій стрілочних переводів та зварювання їх 3 рейковими конструкціями.

3 50-х років на залізницях колишнього СРСР вводилася в роботу безстикова колія, яка виготовлялась за допомогою електрозварювання окремих рейок по 25 м між собою. Довжина таких рейкових ниток, як правило, складала від 250 м та до 800 м. На сьогоднішній день нові вітчизняні технології дають змогу прокладати безстикову колію необмеженої довжини. Це стало можливим завдяки створенню в Інституті електрозварювання ім. Є.О. Патона технології контактного стикового зварювання рейок пульсуючим оплавленням 3 натягом зварювальних рейкових плітей. Укладання безстикової колії, так званого «оксамитового шляху», дасть змогу знизити опір руху поїздів на $12-15 \%$, що приведе до підвищення швидкості руху поїздів до 160200 км/год, покращення плавності та комфортності поїздки, зниження витрат електроенергії на тягу поїздів на $15-18 \%$ за рахунок зменшення опору руху поїздів, скоротить витрати на ремонти колії та рухомого складу до $35 \%$, збільшить строк служби елементів верхньої будови колії і зменшить витрати на стикові скріплення від 5 до 7 т на 1 км [9].

Висновки $з$ дослідження і перспективи, подальшийрозвиток $\mathbf{y}$ даномунапрямку. Розглядаючи світовий досвід для підвищення ефективності функціонування швидкісного залізничного руху в Україні, у теперішній час потрібно:

1. Розвивати пришвидшений рух (до 160 км/год) на основі наявних колій.

2. Підвищити швидкість руху пасажирських поїздів до 200 км/год, для чого необхідно технічно переоснастити колійне господарство 3 подальшою механізацією його технологічних процесів.

3. Упроваджувати високошвидкісний рух, для чого потрібно побудувати окрему нову колію, яка передбачає можливість руху пасажирських поїздів зі швидкістю 200350 км/год. Для цього мають бути задіяні потужності як підприємств залізничного транспорту, так і сторонніх організацій.

4. Розділити вантажні і пасажирські потоки. Для підвищення конкурентоспроможності швидкісних поїздів "IНTЕРСІTI+" необхідно:

- зниження часу подорожі;

- оптимізування графіка руху швидкісних поїздів;

- розширення мережі швидкісних магістралей по всій території України;

- оптимізування величини тарифів 3 метою залучення до швидкісних перевезень додаткових пасажирів;

- упровадження високошвидкісного руху на території України.

Головним напрямом розвитку залізничного транспорту України $€$ створення, а надалі й удосконалення швидкісних, а згодом i високошвидкісних магістралей. Це створить ряд конкурентних переваг не лишедля залізничного транспорту, а й усієї економіки країни внаслідок збільшення пасажирообігу [10].

\section{Список використаних джерел}

1. Босов, А.А. Формирование вариантов рациональной сети линий высокоскоростного движения поездов в Украине [Текст] / А.А. Босов, Г.Н. Кирпа. - Днепропетровск: Днепропетр. нац. ун-т ж.-д. трансп. им. акад. В. Лазаряна, 2004. - 144 с.

2. Пегов, Д.В. Высокоскоростное движение: начало положено [Текст] / Д.В. Пегов // Железнодорожный транспорт. - 2010. - №6. - С. 50-51.

3. Концепція Державної цільової програми впровадження на залізницях швидкісного руху пасажирських поїздів на 2005-2015 роки [Електронний ресурс]: розпорядження Кабінету Міністрів 


\section{Експлуатація залізниць}

України від 31 грудня 2004 р. № 979-р. - Режим доступу: http://zakon2.rada.gov.ua/laws/show/9792004-p.

4. П'ятаченко, Г.Г. Транспортна система України в контексті європейської інтеграции [Текст] / Г.Г. П'ятаченко. - К.: Наукова думка, 1998. - 35 с.

5. Перспектива швидкісного пасажирського руху в Україні [Електронний ресурс]. - Режим доступу: www/URL:http://www.studopedia.info/1-31887.html.

6. Ковалев, В.И. Скоростной и высокоскоростной железнодорожный транспорт [Текст] / В.И. Ковалев; под общ. ред. В.И. Ковалева. - СПб., 2001. - Т. 1. - 320 с.

7. Про схвалення Стратегії розвитку залізничного транспорту на період до 2020 року [Електронний ресурс]. - Режим доступу: www/URL: http://zakon.nau.ua〉doc/?uid=1095.5722.0.

8. Концепція Державної програми реформування залізничного транспорту [Електронний pecypc]. - Режим доступу: http://zakon4.rada.gov.ua/laws/show/1390-2009-п.

9. Предварительное технико-экономическое обоснование проекта высокоскоростных железных дорог в Украине «SYSTRA» [Текст]. - К., 2002.

Рецензент д-р техн. наук, професор О.В. Лаврухін

Запара Ярослав Вікторович, канд. техн.наук, доцент кафедри Управління вантажною та комерційною роботою, Український державний університет залізничного транспорту. Тел.: (057) 730-10-85. E-mail:

y.zapara@gmail.com.

Биков Олексій Володимирович, магістрант кафедри управління вантажною та комерційною роботою Українського державного університету залізничного транспорту. E-mail: nics!990@mail.ru.

ZaparaYaroslav, Ph.D., lecture rof management offreight and commercial work, Ukrainian State University of Railway Transport, tel.: (057) 730-10-85. E-mail:y.zapara@gmail.com.

Bykov Olexiy, master student of the management of trucks and commercial work Ukrainian State University of Railway Transport. E-mail: nics!990@mail.ru.

Наукова праця здана до друку 24.06.2015 року 